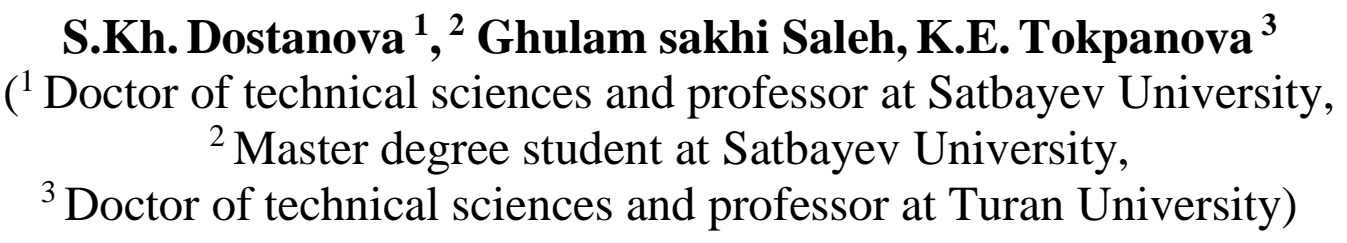

\title{
ADVANTAGES OF SEISMIC ISOLATION OF BUILDINGS AND STRUCTURES
}

Annotation. The article discusses the benefits of using seismic isolation for buildings and structures. The results of many studies of major world earthquakes are presented. The use of seismic isolation reduces the effects of earthquakes and increases the safety margin and safety of buildings and structures.

Key words: Seismic isolation, isolated building, conventional building, earthquake, ductility, structural damage, horizontal seismic effects, displacements, acceleration.

Seismic isolation is a technique that has been used around the world to protect building structures, nonstructural components and content from the damaging effects of earthquake ground shaking. It offers the highest degree of earthquake protection to buildings and their inhabitants. The modern application of seismic isolation technology for buildings and structures is less than 50 years old, and its distribution in seismically active regions continues to grow rapidly. The benefits of seismic isolation that make it attractive to building owners are considered in two options: first, benefits realized before the occurrence of a damaging earthquake, and second, the benefits experienced during and after such an event.

Consider the benefits of seismic isolation of buildings before earthquakes [1-9]. This is especially true for complex objects such as nuclear power plants. The Fukushima accident has reiterated that the seismic safety is a clear necessity in the design of nuclear power plants. To overcome the weaknesses of the plant design, appropriate measures or interventions have thus to be put in place to improve the nuclear safety [3]. In this study, seismic isolation, widely adopted for conventional constructions, is considered as retrofit measure to provide superior performance of plant itself, even when exceptional events occur. In this paper, we numerically investigate the dynamic behaviour of a Small Modular Reactor (SMR) plant subjected to 0.6g PGA; in doing that time-history analysis has been performed assuming the reactor building with and without isolators. For that purpose, a suitable FEM model has been implemented to provide in-structure response spectra at safety relevant locations and subsystem supports. Adequate steel and concrete properties as well as isolators properties, experimentally determined, have been assumed. Results have shown the benefits of seismic isolation for NPP that can so sustain levels of loading beyond the design input and demonstrated that failure of an isolation system cannot occur before failure of the isolated structure. However, the large horizontal displacements of the structure require appropriate considerations in the layout and interfaces for interconnected systems. 
Surprisingly, seismic isolation can deliver benefits even before an earthquake strikes. Many of these benefits are realized during the design phase of a building when they can lead to improved architectural features. Take, for example, the size of and configuration of structural members. Although seismically isolated buildings are generally designed to be as strong as equivalent conventional buildings, they do not need the same capacity for ductility. Their energy absorption is provided by their damping mechanisms. In conventional buildings ductility is achieved by applying the Capacity Design approach. First, by ensuring a hierarchy of structural damage whereby the most vital structural elements, such as columns that support the whole building weight, have greater protection than say beams.

Beams can support their loads even if damaged at their ends. Second, brittle failure modes such as shear failure are suppressed by increasing the shear strength of structural members such as columns, beams and structural walls. Then, earthquake energy can be absorbed by the yielding of structural steel, or steel reinforcement in reinforced concrete structures, at non-critical discrete locations throughout the structure.

Such ductile conventional buildings, at least if they rely upon moment frames for their horizontal resistance, require regular inter-story heights and columns stronger than beams. But since seismically isolated buildings are normally designed to remain elastic, there is not the same need for vertical regularity. Some of the traditional rules for sound seismic configuration can be eased. For example, normally very undesirable soft story and short column configurations that are normally considered critical structural weaknesses may be possible given that structural members are protected from damage by seismic isolation. This potential is exploited in a seismically isolated Japanese building with very slender columns and long-span beams.

As well as preventing structural damage, seismic isolation reduces greatly the horizontal inter-story drifts that occur during an earthquake. Where a need to reduce horizontal flexibility rather than meet strength requirements drives the sizes of structural members, seismic isolation enables smaller structural member sizes. Other significant architectural advantages arise in a building subject to less inter-story drift. These include reduced seismic separation gaps between architectural elements, such as glazing and mullions, or exterior cladding units such as precast concrete panels, and between architectural elements and structural members. The outcome is simplified, less visually prominent construction detailing.

Seismic isolation then offers the possibility of more architectural freedom. Structural configurations unthinkable in conventional buildings can be considered. More slender columns and structural walls are also feasible, as well as simpler and thinner separation gaps. These potential benefits can improve architectural aesthetics. Two examples designed by Toyo Ito are discussed in more detail in the following chapter.

But pre-earthquake benefits include more than those related to architectural quality. Seismic isolation offers peace of mind to building owners and occupants. This is reflected in increasing numbers of seismically isolated Japanese apartment buildings. Seismic isolation, marketed as one of the desirable features of these buildings, attracts 
both tenants and increased rentals. There also may be other financial benefits for owners such as being able to negotiate reduced earthquake insurance premiums or even self-insure.

It is far less traumatic experiencing an earthquake in a seismically isolated building. The building sways relatively slowly as compared to a conventional building where you are likely to be subject to violent shaking. The lower accelerations in an isolated building also mean less damage to building contents. Less flinging and falling of items from shelves or desk-tops also lowers anxiety levels and reduces injuries. Smaller inter-story deflections mean glazing is less likely to be damaged or cladding panels are less likely to fall from badly distorted frames onto footpaths below.

Reduced accelerations and deflections are the norm in isolated buildings. For example, Istanbul's Sabiha Gokcen Airport, one of the largest seismically isolated buildings in the world, is predicted to experience up to 80 percent reduction in interstory drifts and floor accelerations.

Istanbul's Sabiha Gokcen international Airport Terminal, Turkey, one of the largest seismically isolated buildings in the world. Non-structural damage to a suspended ceiling at the Santiago International Airport terminal building after the $27 \mathrm{Feb}-$ ruary 2010 Chile earthquake [2]. A consequence of no or limited damage is minimal disruption to building occupancy and function. Of course, the building must remain unaffected by damage to neighboring buildings and to utilities such as electricity, sewage and water supply, and remain accessible. For some enterprises minimization of downtime is very important. Efforts to quantify post-earthquake costs, including those associated with building downtime, are included in lifecycle cost analysis for seismic isolation systems.

Seismic isolation is currently represented by numerous devices. Many devices have experimentally confirmed that buildings can work as intended, i.e. provide high attenuation input excitations so that the structural system remains elastic with large horizontal vibrations of the soil. Base isolation is one of the most powerful tools of earthquake engineering pertaining to the passive structural vibration control technologies. The isolation can be obtained by the use of various techniques like rubber bearings, friction bearings, ball bearings, spring systems and other means. It is meant to enable a building or non-building structure to survive a potentially devastating seismic impact through a proper initial design or subsequent modifications. In some cases, application of base isolation can raise both a structure's seismic performance and its seismic sustainability considerably. Contrary to popular belief base isolation does not make a building earthquake proof [9]. Base isolation system consists of isolation units with or without isolation components, where:

1. Isolation units are the basic elements of a base isolation system which are intended to provide the aforementioned decoupling effect to a building or non-building structure.

2. Isolation components are the connections between isolation units and their parts having no decoupling effect of their own. 
Isolation units could consist of shear or sliding units. Example, of the many devices that have been tested, a handful of devices (elastomeric bearings, lead-rubber bearings, Friction PendulumTM, and Triple PendulumTM) claim the majority of the market share in the United States and around the world. Sufficient research has been conducted to suggest that base-isolated buildings can be detailed to survive earthquake events larger than anticipated in design, through activation of one or more ultimate limit state behaviors such as: unrestrained uplift, rupture of elastomeric bearings under tension and shear, buckling of elastomeric bearings, engagement of a displacement restraint or large displacement hardening. Many of these ultimate behaviors of the isolation system will redistribute demands to the superstructure, which should ultimately be detailed for ductile response.

\section{Summary}

The results of numerous theoretical and experimental studies have shown that the adoption of seismic isolation is beneficial for buildings and structures that can withstand load levels beyond any possible seismic effects. In addition, they demonstrated that failure of the insulation system cannot occur until the failure of the insulated structure. Because for buildings, the most dangerous are horizontal seismic effects, therefore, insulating devices sharply reduce horizontal acceleration and spectra of seismic reactions; therefore, the seismic requirements of structures in the low frequency range are significantly reduced.

\section{Reference:}

1. Static and dynamic stability of elastomeric bearings for seismic protection of structures. $J$ Sanchez, A Masroor, G Mosqueda, K Ryan// Journal of structural engineering 139 (7), 2013. P. 1149-1159.

2. Performance of nonstructural components during the 27 February 2010 Chile earthquake. E Miranda, G Mosqueda, R Retamales, G Pekcan. Earthquake Spectra 28 (1_suppl1), 2012, p. 453-471.

3. Benefits of Seismic Isolation for Nuclear Structures Subjected to Severe Earthquake. Journal of Science and technology of Nuclear installations. - Volume. 2018. ID 8017394. 11 pages. https://doi.org/10.1155/2018/8017394.

4. J. M. Kelly and D. A. Konstantinidis Mechanics of Rubber Bearings for Seismic and Vibration Isolation. - Wiley, 2011.

5. S. Nagarajaiah and S. Xiaohong Response of base-isolated USC hospital building in Northridge earthquakel/ Journal of Structural Engineering, vol. 126, no. 10, pp. 1177-1186, 2000.

6. C.G. Koh and J. M. Kelly A simple mechanical model for elastomeric bearings used in base isolation// International Journal of Mechanical Sciences, vol. 30, no. 12, pp. 933-943, 1988.View at: Publisher Site | Google Scholar

7. S. Marzano A one-dimensional model for finite deformations of multilayered rubber bearings// International Journal of Solids and Structures, vol. 31, no. 15, pp. 2121-2138, 1994.View at: Publisher Site | Google Scholar

8. R. Lo Frano and G. Forasassi Evaluation of Instability of Laminated Rubber Bearings under Dynamic Loading in Proceedings of the ICAPP, San Diego, Calif, USA, June 2010.

9. "Seismic Isolation | [ THK || Global English ]". www.thk.com. 
Мақұалада вимараттар мен құрылыстар үшін сейсмикалық оқшаулауды құолданудың артықшылықтары тураль айтылады. Әлемдік ірі жер сілкіністерін зерттеудің көптеген нәтижелері келтірілген. Сейсмикальқ оқұшаулауды қ̧олдану жер сілкінісінің әсерін азайтады және вимараттар мен құрылыстардың қауіпсіздігін арттырады.

Түйін сөздер: сейсмикалық оқмаулау, оқмауландан вимарат, ддеттегі вимарат, жер сілкінісі, икемділік, құрылылмның зақылмдануы, көлденең сейсмикальққ әсерлер, орын ауыстырулар, удеу.

В статье рассматриваются преимущества использования сейсмозащиты для зданий и сооружений. Представлены результаты многих исследований крупных землетрясений мира. Использование сейсмической изоляции снижает последствия землетрясений и увеличивает запас прочности и безопасность зданий и сооружений.

Ключевые слова: сейсмическая изолячия, изолированное здание, обычное здание, землетрясение, пластичность, структурные повреждения, горизонтальные сейсмические воздействия, смещения, ускорение. 